\title{
The art of establishing and maintaining contact with ancestors: A study of Bapedi tradition
}

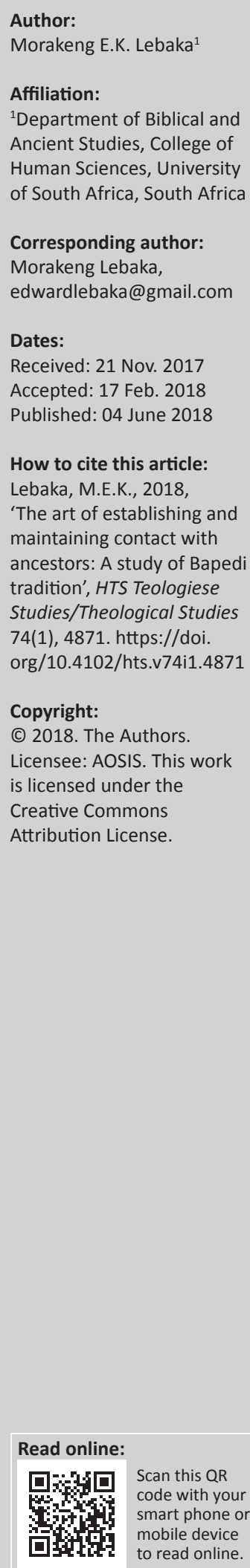

\begin{abstract}
Looking at Bapedi ancestor veneration constructively, one finds it a source of communication that enhances the community's norms, values and personal well-being. The Bapedi community has a belief system that is based on the spiritual world, and this includes ancestor veneration. Communication with the spiritual world happens through sacrifices, songs and dance. Malopo is a ritual that not only binds the people to their ancestors (the ancestral realm) but also provides a healing therapy. The purpose of this study was to investigate the religious and social functions of ancestor veneration in the Bapedi society, as well as the relationship between culture, music and identity in veneration in the traditional healing Sepedi context. To achieve this aim, the study employed a naturalistic approach and data were collected through video recordings of malopo rituals, interviews and observations. The main questions the study addressed are (1) what are the religious and social functions of ancestor veneration in the Bapedi society? and (2) what is the relationship between culture, music and identity in veneration in Sepedi traditional healing context? The results demonstrated that ancestors are vital to Bapedi society, and the most effective ways of reaching them are through music and dance-malopo rituals, as well as divination bones.
\end{abstract}

\section{Introduction}

Bapedi are an ethnic group situated mainly in the central district of Sekhukhune, in Limpopo Province. They include several clans, for example, Barwa, Bakone, Bakgaga, Baroka and Bakopa. There is a general belief that ancestors have the potential power to affect the living, both for good, if they are respectfully and properly venerated, and for evil, if their veneration ${ }^{1}$ is neglected. Bapedi believe that their ancestors continue to play a prominent role in their families and should be consulted by their offspring. These ancestors are not worshipped in the true sense of the word, but rather venerated. Mbiti (1970:264) endorses this observation by stating, 'African people believe that death does not annihilate life and the departed continue to exist in the hereafter'. This view is reinforced by Willoughby (1928:89), who observes that death does not even effect any change in the character of the departed. In Willoughby's view, 'ancestors' characters have not been changed by death, but they are as prone to jealousy as they ever were'. Imasogie (1985:37) agrees with Mbiti (1970:264) and Willoughby (1928:89) when he notes that the ancestral spirits are also the guardians of morality in the family circle'. He confirms that ancestors see to it that there is no permanent feud between earthly members of the family. Along similar lines it is worthwhile to mention here Simon's view. In a personal interview, Madikedike Simon Sete ${ }^{2}$ (16 June 2006) at Dingwane Village, Sekhukhune District, pointed out that the life of Bapedi has always been based religiously, culturally and socially upon ancestor veneration. According to him, like many other African societies, Bapedi create music to accompany religious and social rituals as well as to reflect on human experiences (Lebaka 2017:75). Sete further mentioned that when Bapedi ancestors need to be consulted, the most effective ways of reaching them are through music and dance - the malopo ritual, as well as divination bones (see Figure 1).

Sete is convinced that the use of music (i.e. the integration of singing, dancing or any other body movements and playing of instruments) to please the ancestors and to communicate with them is widespread in Bapedi society (see Figure 2). Sete's views are supported by Matshege Christinah Molangwana, ${ }^{3}$ senior traditional healer (pers. comm., 24 July 1998), who

\section{The word veneration implies that respect is accorded to the elders by the young ones. Veneration requires much respect.}

2.Madikedike Simon Sete is Edward Lebaka's personal family friend. He is a teacher by profession. After working in this capacity for 5 years, he resigned as a teacher, since his grandfather had instructed him to become a traditional healer. He was born in 1962 at Kotsiri Village (Schoonoord) in Sekhukhune District. This man made it possible for Morakeng Edward Kenneth Lebaka (researcher) to have access to the circle of traditional healers during malopo rituals. He specializes in many diseases and symptoms of ill health, for example access to the circle of traditional healers during
insanity, cancer, asthma, etc. (Lebaka 2017:75).

3.Matshege Christinah Molangwana is a senior traditional healer. She was born in 1952 at Dingwane Village (Schoonoord) in Sekhukhune District. Matshege was influenced by her grandfather, Lehumo Frans Mmotla, to become a traditional healer in 1989. Currently, she specializes in many diseases and symptoms of ill health, for example insanity, depression, cancer, etc. (Lebaka 2017:74). 


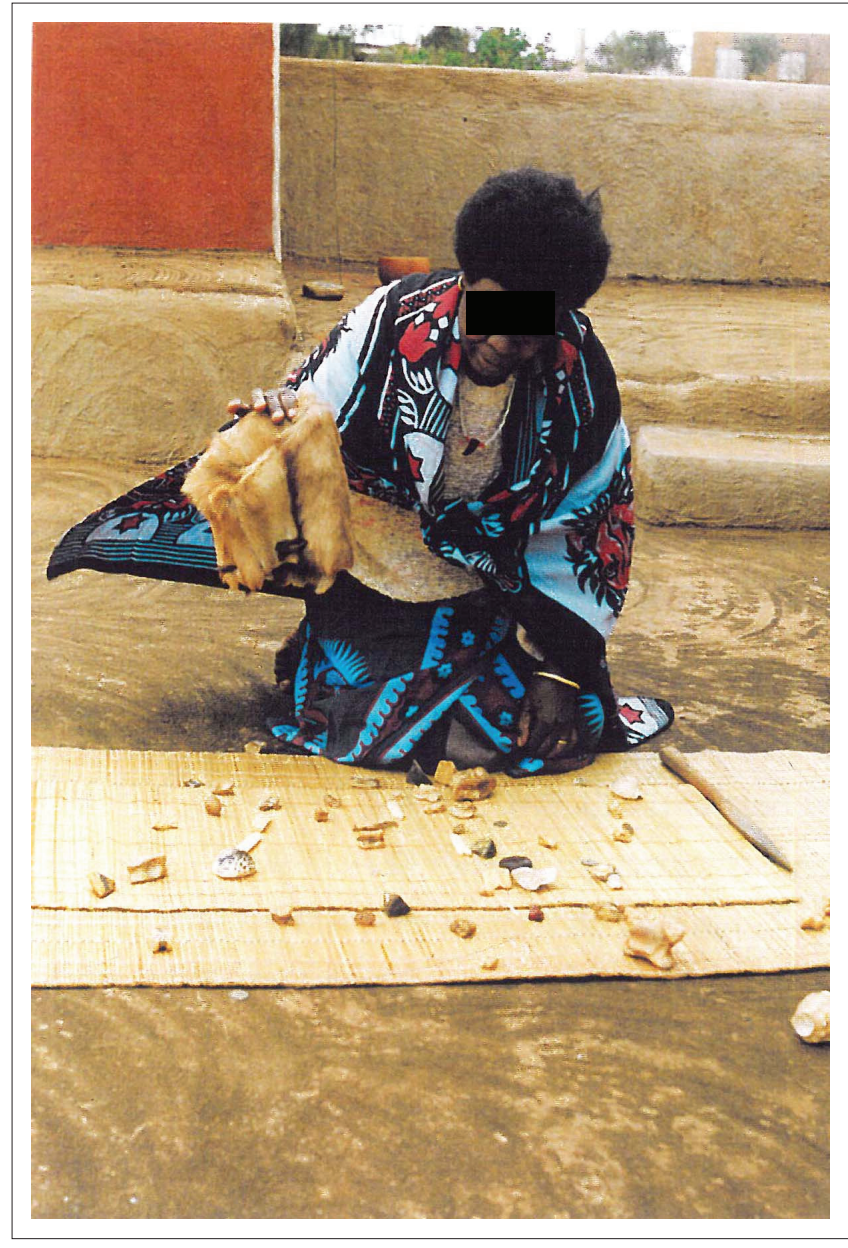

Source: Photo provided by Morakeng Edward Kenneth Lebak

FIGURE 1: Kgongoana Mariam Seepe, a traditional healer, throwing divination bones to determine the cause of hardship (Kotsiri Village, 22 July 1998)

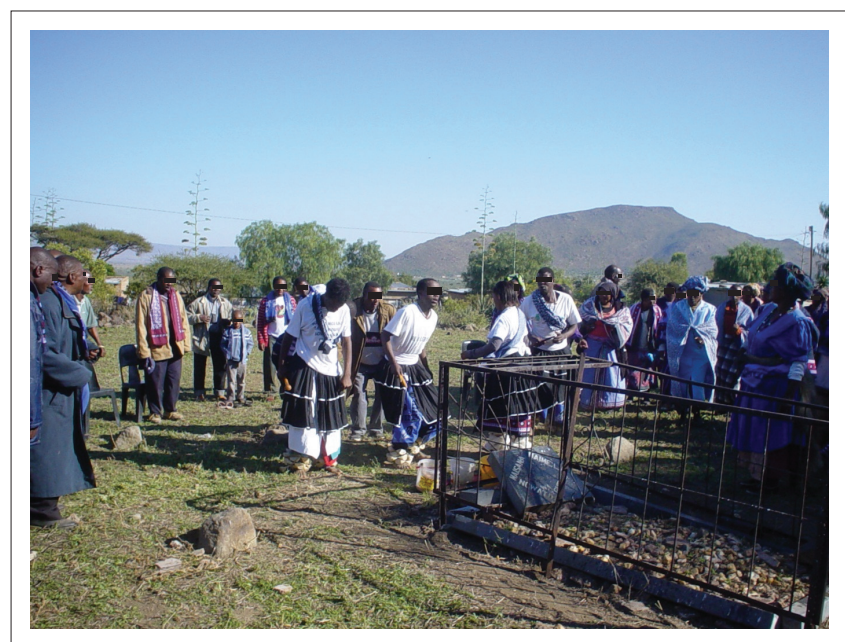

Source: Photo provided by Morakeng Edward Kenneth Lebaka

FIGURE 2: Songs sung and recited during ancestor veneration at the cemetery in order to create harmony between the living and the ancestors (Mashite Village, 17 March 2003).

observes that communication between the traditional healers and their personal ancestors happens through dreams (ditoro) and music. In her view, songs are sung and recited in order to create harmony between the living and the ancestors.

\section{Previous related research}

It has become evident from a thorough review of the literature that there is little known about ancestor veneration as a product of Bapedi, who are bound by a common traditional religion, music and cultural values, as well as the relationship between culture and music in veneration in the traditional healing context of Bapedi. Written sources providing information on music and dance in healing, as well as culture, music and identity in veneration in the African context, were studied, and books and other sources describing the religious and social functions of ancestor veneration in the African context were also consulted to establish a literature review. The observations and arguments that have been brought forward in the literature are discussed below.

\section{Music and dance in healing}

The relationship between music and dance in healing has been researched by scholars such as Berliner (1981), Boddy (1994), Comaroff (1985), Gouk (2000), Gray (1991), Hindley (1982), Kongo (1997), Nzewi (1991, 2003) and OmibiyiObidike (1998). For example, Hindley (1982), Kongo (1997), Nzewi (2003) and Omibiyi-Obidike (1998) reported the use of music and dance in healing as an accompaniment to healing rites in different parts of Africa. Scholars of African healing such as Berliner (1981), Comaroff (1985), Gray (1991), Boddy (1994) and Gouk (2000) confirm the relative importance of music in healing. In particular Gouk (2000:171) confidently claims that 'music plays a significant role as a symbol of the priest-practitioner's power, particularly as regards his control of spirits and deities'. Attesting to the observations above, Madikedike Simon Sete, senior traditional healer (pers. comm., 24 July 1998), confirms that the malopo ritual is not just for entertainment purposes but acts as a cohesive force and a healing link between Bapedi and the ancestral realm.

Furthermore, Simon observes that malopo in the Sepedi context refers to a complex of disorders supposedly all because of possession by ancestral spirits, which are to be cured only by the therapeutic ritual of performing the malopo dance. In his view, music and dance for healing purposes is very common in the Bapedi community. Sharing Simon's views, researchers and scholars of African music and religion have observed the rich cultural heritage of the Africans. Olivier (1985), Van der Hooft (1979), Ephirim (1997), Firth et al. (1969), Huskisson (1958:122) and Ray (1976:17) agreed that in Africa, dance and music are essential elements of life. ${ }^{4}$ According to Olivier (1985:2), Bapedi believe that the illness of malopo can only be terminated by the ngaka ya malopo (malopo doctor) through a ritual called malopo, which involves dancing by the patient as well as by the malopo cult members.

Other numerous research publications that contain great depth of knowledge on music and dance in healing include scholars such as Mashabela (2017), Mugovhani (2015),

4.Hammond (2004:105) maintains that music, which acts partly on a conscious and partly on an unconscious or emotive level, is therefore frequently a way to articulate those aspects of our character of which we are not consciously aware. 
Garfias (2004) and Merriam (1982). These scholars confirm that music is often associated with ceremony and ritual. In particular, Mashabela (2017:12) writes, 'with regard to healing in a cultural context, there is a need for Africanisation that listens to black indigenous knowledge and voices from an African perspective'. Garfias (2004:11) agrees with Mashabela by indicating that 'music in connection with religious ceremonies, as with any use of music in the culture, can tell us much about how music is regarded and how it functions in that culture'. In his view, in some societies music serves as an important accompaniment to ritual. Expanding on the idea of music as a tool for the preservation of cultural heritage and identity, Mugovhani (2015:s94) emphasises that African indigenous music, permeating the whole gamut of African life (socio-cultural, socio-religious, political, etc.) and predating colonial days, defines and identifies Africans. Merriam (1982) supports the purposeful use of music to improve our lives and asserts that 'African music is functional in almost all aspects of life'.

\section{Culture, music and identity in veneration}

Scholars pursuing research on the relationship between culture, music and identity have produced many learned writings. Some of these studies include Idang (2015), Davhula (2008) and Etuk (2002). Idang (2015:2) confidently advocates that culture, as it is usually understood, entails a totality of traits and characters that are peculiar to a people to the extent that it marks them out from other peoples or societies. According to him, these peculiar traits go on to include the people's language, dressing, music, work, arts, religion, dancing, social norms, taboos and values. In consonance with the above observation, Davhula (2008:129) notes that 'there is something else about the way music functions in our culture that is noteworthy'. She observes that 'our songs may be the most effective means we have of defining ourselves as a group, of refining our emotions and perhaps of helping us to clarify even our thoughts'. Attesting to the observations above, Etuk (2002) writes:

an entire way of life would embody, among other things, what the people think of themselves and the universe in which they live - their world view - in other words, how they organise their lives in order to ensure their survival. (p. 13)

He is of the opinion that it can be safely stated that there can be no culture without a society.

\section{Religious and social functions of ancestor veneration}

A number of scholars in various literary sources have also written about the functions of ancestor veneration in religious and social contexts. Included in this concept are Mashabela (2017), Idang (2015), Garfias (2004) and others. With regard to African religion and spirituality, Mashabela (2017:6) writes, 'the well-being of the African's spirituality and reality cannot be ignored as being part of an African worldview'. According to him, only Africans can determine and interpret their African spirituality. In his research, Idang (2015:7) found that religion in African societies seems to be the fulcrum around which every activity revolves. He argues that 'African traditional religion, wherever it is practised, has some defining characteristics'. In his view, it possesses the concept of a supreme being who is invisible and indigenous. According to him religion holds a belief in the existence of the human soul and the soul does not die with the body. The latter view brings an assumption to the fore. Garfias (2004:12), for instance, assumes that early humans may have at first made music as a re-creation of the activities of a hunt, as appeasement to the powerful spirits or as a way of healing the sick.

\section{Aims}

The purpose of this study was twofold: to investigate (1) the religious and social functions of ancestor veneration in Bapedi society and (2) the relationship between culture, music and identity in veneration in a traditional Sepedi healing context. The main questions the study addressed are (1) what are the religious and social functions of ancestor veneration in Bapedi society? and (2) what is the relationship between culture, music and identity in veneration in the traditional Sepedi healing context?

\section{Research methodology}

Data collection used a naturalistic approach and the methods of data collection were video recordings of malopo rituals, interviews, observations and a literature review. The study was conducted in three phases; the first phase involved visiting and interviewing traditional healers who participated in malopo rituals. In this case both oral interviews and observation schedules were employed to gather information. Eleven of the most important dingaka [traditional healers] from seven villages were randomly selected from the sixtyfive traditional healers who were included in the research (see Table 1). Each interview took approximately two hours. An initial as well as a follow-up interview was held with each ngaka [traditional healer]. The gender, age, village and language distribution are given in Table 1.

TABLE 1: Number, gender, ages and languages of the traditional healers interviewed, as well as the names of villages they come from.

\begin{tabular}{lc}
\hline Gender, ages, villages and languages of traditional healers & Number \\
\hline Gender & 5 \\
Male & 6 \\
Female & \\
Ages & - \\
$20-25$ & 2 \\
$26-35$ & 9 \\
36 and over & \\
Villages & 1 \\
Schoonoord (Kotsiri) & 3 \\
Schoonoord (Dingwane) & 1 \\
Tshehlwaneng (Ga-Makgeru) & 2 \\
Dikgageng & 2 \\
Schoonoord (Ga-Maloma) & 1 \\
Ga-Moloi & 1 \\
Jane Furse (Madibong) & 11 \\
Languages & \\
Sepedi &
\end{tabular}


From Table 1, we observe that all participants were Sepedispeaking. Of the traditional healers interviewed, six were female and five were male. The ages of the traditional healers ranged from 30 to 72 years. Villages included Kotsiri, Dingwane, Tshehlwaneng, Dikgageng, Ga-Maloma, Ga-Moloi and Madibong.

The second phase was direct observation of the malopo rituals. Nine Pedi malopo rituals were purposefully chosen so they could be observed and recorded using videos and photographs to provide information on ancestor veneration in Bapedi society. The videos and photographs were analysed with regard to the religious and social functions of ancestor veneration in the Bapedi society, as well as the relationship between culture, music and identity in veneration in the traditional Sepedi healing context. The effects of the music and dance movements on participants were observed and recorded as notes. The communication of traditional healers and trainees with their ancestors was observed during malopo rituals.

The third phase was a literature review. The literature review surveyed available literature regarding (1) the religious and social functions of ancestor veneration in Bapedi society and in Africa and (2) the relationship between culture, music and identity in veneration in the traditional healing contexts, namely Bapedi and African.

\section{Results}

\section{Functions of ancestor veneration in Bapedi society}

The results were obtained from all phases - the interviews, direct observation and literature review. The results of analysing the social and religious functions of ancestor veneration, as well as the influence of malopo rituals on participants, are described below.

\section{Religious functions of ancestor veneration}

The functions of ancestor veneration in Bapedi society were obtained from a review of the literature and observations, as well as the interviews collected during this study. The research demonstrated that ancestors play a prominent role among families in Bapedi society. During the study, informal discussions with traditional healers and participants during malopo rituals revealed that the relationship between Bapedi and their ancestors was not always a harmonious one. Morongwa Angelinah Tshehla, ${ }^{5}$ a traditional healer (pers. comm., 16 June 2006), stated:

Before I became a traditional healer, I was very ill and unable to sleep. One night when I was asleep, I had a dream of a man coming to me and giving me an old plastic bag full of divination bones. By then I was a full member of Zion Christian Church (ZCC). I then decided to tell the church pastors about my

5.Morongwa Angelinah Tshehla is a traditional healer. She was born in 1967 at Ga-Maphopha (Dikgageng Village) in Sekhukhune District. She is a teacher by profession. Morongwa was influenced by her grandfather Tšabadi Tšabadi to profession. Morongwa was influenced by her grandfather in 1991. Currently, she specializes in many diseases and become a traditional healer in 1991. Currently, she specializes in many diseases and
symptoms of ill health (e.g. women with pregnancy problems, bewitched people, diarrhea and swollen legs). problems, and they instructed me to carry out [a] few instructions for recovery. One of the instructions was for me to drink dirty water with my hands behind my back on arrival at home. I deliberately ignored the instruction and two days after my consultation with the church pastors, I experienced physical visitation of snakes. I found the first snake in my pillowcase at night (20:00). My mother-in-law, Hunadi Malebatse, assisted me in killing the snake. I then went back to the church (ZCC) to tell them about the snake, and their response was: I did not carry out the instruction they had given me. They warned me that in case I am not willing to carry out the instruction, I will see the biggest snake I have ever seen. After two weeks, the biggest snake I was told about at Moriya (ZCC) came to my bedroom. The circumference of the snake could have been approximately $75 \mathrm{~cm}$. After killing the snake, my husband and I then travelled to Bushbuckridge to consult with John Ndlovu, a traditional healer, who through divination bones revealed that my grandfather, Tšabadi, was a traditional healer and wants me to become a traditional healer. He confirmed with us that in case of acceptance of the call/offer all the snakes, pains and sleepless nights will disappear. My husband and I agreed that I [would] accept the call. John Ndlovu then referred me to Madikedike Simon Sete, who resides at Kotsiri village (Schoonoord) as an appropriate traditional healer for training. Back from Bushbuckridge we went to Kotsiri village, to consult with Madikedike Simon Sete. Through divination bones, Simon also confirmed that Tšabadi Tšabadi is my personal ancestor and wishes me to become a traditional healer. I spent one year (12 months) for training as a traditional healer, learning singing, drumming, dancing, divination bones and medicines, and was officially welcomed back home with [a] malopo ritual on the 15th of November 1997, and all the pains, snakes and sleepless nights have disappeared.

Kgongoana Mariam Seepe ${ }^{6}$ a traditional healer (pers. comm., 16 June 2006), endorses Angelinah's experience by stating:

I was a pastor of St John Apostolic church at Kotsiri village in Sekhukhune district (Limpopo province), and I did not even think of becoming a traditional healer. I was baptizing people. My personal ancestor is my brother-in-law, the late Ditedu Bogopa. In a dream he accused me of having abandoned what he had taught me (namely, to identify and dig out medicines). A few days later, I became very ill and I could not sleep. Always when the sun set, I became worried, for I knew I was not going to sleep well. I then decided not to go to church because he very often visited me. At times I collapsed when walking on the street, because I was gradually losing a tremendous amount of weight. I deemed it necessary to consult with the traditional healer, Madikedike Simon Sete of Kotsiri village (Schoonoord). Through divination bones, he confirmed everything I knew about my personal ancestor, the late Ditedu Bogopa. I spent only one year at Sete's home training as a traditional healer. I have learnt the singing, dancing, drumming, divination bones and medicines associated with the profession. In 1988 I was certified as a qualified traditional healer and was officially welcomed back home with $[a]$ malopo ritual. I am currently a traditional healer and my personal ancestor is no longer angry with me. Always when he visits me, he only shows me medicines to dig out and informs me of the patients coming for consultation but also of the witches who would like to hamper my progress or any

6.Kgongoana Mariam Seepe is a traditional healer. She was born in 1945 at Kotsiri Village (Schoonoord) in Sekhukhune District. Kgongoana was influenced by her brother-in-law, Ditedu Bogopa, to become a traditional healer in 1987. Currently, brother-in-law, Ditedu Bogopa, to become a traditional healer in 1987. Currently,
she specializes in many diseases and symptoms of ill health (e.g. insanity, depression, asthma and bewitched people). 
attempt to kill me. My health has improved satisfactorily, and I now sleep well like everyone else.

In the light of the above testimony of the existence of ancestors in Bapedi culture and the problems encountered by Morongwa and Kgongoana, it is evident and a clear indication that defying ancestors' instructions might cause one to suffer from ill health, sleepless nights and even to experience frightening experiences like Morongwa and Kgongoana. There is much wisdom in the above testimony by Morongwa and Kgongoana. The testimony provides enlightenment to the reader concerning the relationship between ancestors and their offspring in Bapedi society. With regard to ancestor veneration as a product of Bapedi, who are bound by a common traditional religion, music and cultural values, it was found that the life of the Bapedi has always been based religiously, culturally and socially upon ancestor veneration. Lebaka (2017), for instance, states that:

[i]rrespective of the differences in terms of dialect and cultural features from one clan to the other within Bapedi community, all Bapedi are bound together in a related ethnic musical tradition. (p. 42)

The above information correlates with the observation of Mamagabe Michael Tjabadi, ${ }^{7}$ a traditional healer (pers. comm., 16 June 2006), namely that 'in Bapedi culture, gatherings of communal ancestor veneration are usually accompanied by ululating, instrumental playing, singing and dancing' (see Figure 3). Mamagabe intimates that, 'for Bapedi, malopo songs are both an expression and a contribution to Bapedi religious ritual experience within this specific cultural group'.

\section{Social functions of ancestor veneration}

There is a general belief in Bapedi society that the main desire of ancestors is to be remembered by their offspring. This observation is endorsed by Matshetla Sarah Mmotla, ${ }^{8}$ a traditional healer (pers. comm., 16 June 2006), who states that Bapedi observe the practice of venerating their ancestors. According to Matshetla, the motivation behind the veneration is to invoke and share communion with ancestors. Attesting to the opinion above, Mönnig (1967:54) writes, 'if this is done faithfully, they reward the living through good health for themselves and for their livestock, plentiful rains and good harvests'. The impression created during interviews and

\footnotetext{
7.Mamagabe Michael Tjabadi is a traditional healer. He was born in 1954 at Dikgageng Village (Ga-Maphopha) in Sekhukhune District. Mamagabe was influenced by his grandfather, Lekolo Maepa, to become a traditional healer. In 1978, when he was in grandfather, Lekolo Maepa, to become a traditional healer. In 1978, when he was in
standard 6 (Grade 8) at Ngwaabe Secondary School, at Ngwaabe Village in Sekhukhune District, he became very ill. When he was in the classroom, he saw darkness, which prevented him from writing and reading. He then informed his teacher, Mr Manchidi, about his problem, who advised him to go home and tell his parents. His parents took him to the traditional healer, Thomas Nkwana, in Mandagshoek next to Burgersfort, who told them that Mamagabe was not bewitched, but inspired or possessed by the ancestral spirits. Mamagabe and his parents then reached a consensus that Mamagabe would start training as a traditional healer under the tutelage of Thomas Nkwana. Currently, he specializes in many diseases and symptoms of ill health (e.g. insanity, headache, witchcraft, swollen legs, diarrhea, etc.).

8.Matshetla Sarah Mmotla is a traditional healer. She was born in 1933 at Dingwane Village (Schoonoord) in Sekhukhune District. Matshetla was influenced by her grandfather Klaas Tsheegana to become a traditional healer. Currently, she specialises in many diseases and symptoms of ill health (e.g. insanity, diarrhea, witchcraft, etc.).
}

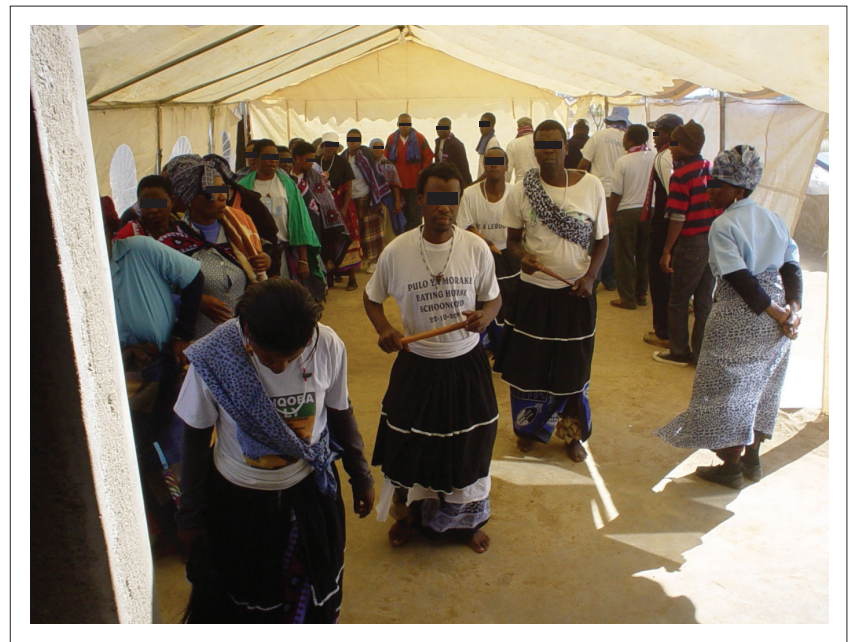

Source: Photo provided by Morakeng Edward Kenneth Lebaka

FIGURE 3: Ancestor veneration (malopo ritual) accompanied by ululating, instrumental playing, singing and dancing to appease the ancestral spirits (Ga-Moloi Village, 17 March 2003).

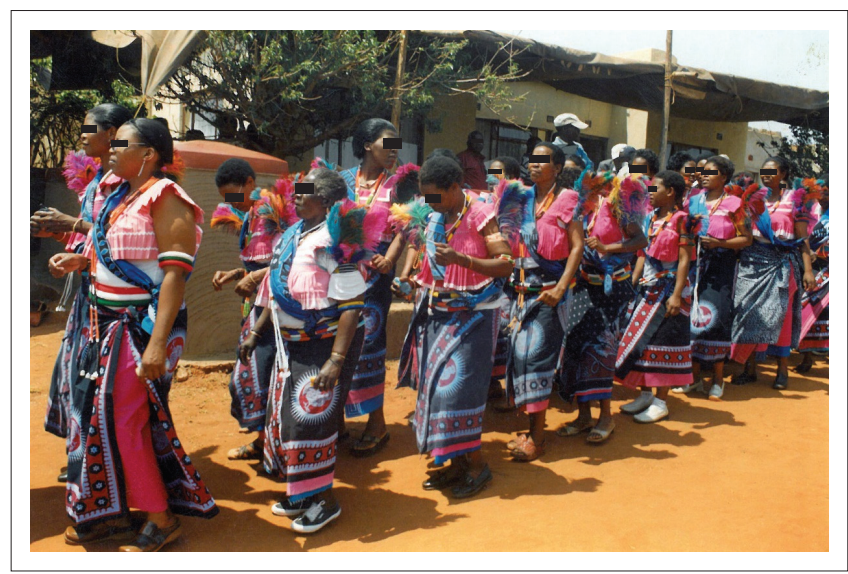

Source: Photo provided by Morakeng Edward Kenneth Lebaka

FIGURE 4: Trainees (mathasana) as part of ancestor veneration to appease the ancestral spirits (Kotsiri Village, 17 March 2003).

observations was that malopo ritual, more than being a process of communication with the ancestors, is a product of the art itself. As a product, it exists to provide religious, social and cultural functions of ancestor veneration in Bapedi society. For example, during the study it was observed that no word is wasted in malopo music; they are all aimed at communicating specific messages idiomatically, proverbially or directly to the audience.

Although several oral accounts claim that communication with ancestors is often facilitated by traditional healers who participate in malopo rituals, during the study it was observed that both traditional healers and the trainees (see Figure 4) need ancestor veneration to appease the ancestral spirits, once a personal ancestor begins the initiation process (Lebaka 2017:75). This observation is supported by Manare Anna Lekwana, ${ }^{9}$ a traditional healer (pers. comm., 16 June 2006),

9.Manare Anna Lekwana is a senior traditional healer. She was born in 1930 at Dingwane Village (Schoonoord) in Sekhukhune District. Manare was influenced by her father, Tsabuke Maloma, to become a traditional healer. Currently, she by her father, Tsabuke Maloma, to become a traditional healer. Currently, she
specializes in many diseases and symptoms of ill health (e.g. insanity, women with pregnancy problems and bewitched people). 
who observes that 'for healing to take place, a traditional healer has to ask the ancestral spirits for guidance' (Lebaka 2017:75). Nurnberger (2007:154), whose study incidentally coincides with the present study, argues that ancestors are meant to protect, strengthen and bless their offspring, but they are not omnipotent.

\section{Discussion}

\section{Culture, music and identity in veneration}

What has emerged thus far in this study is that malopo ritual is part of Bapedi culture, as Bapedi culture is part of malopo ritual. To prove this point, in Bapedi society, the performance of a malopo ritual proves the religious, social and cultural significance of ancestor veneration in music in African life and thinking. ${ }^{10}$ The findings also imply that malopo songs are sung and recited in order to appease the ancestors. It is evident from this study that the ancestor veneration of Bapedi is based on the belief that ancestors are still recognised as part of the family. Their main desire is to be remembered, honoured and respected.

Reviewing the results yielded thus far, it is clear that in Bapedi society, ancestor veneration, wherever it is conducted, comprises traditional beliefs, customs and practices, which are directed towards the ancestors. Closer investigation has shown that Bapedi have ways of establishing and maintaining contact with their ancestors. These include ancestor veneration through religious, social and cultural rituals, as well as divination bones. This interpretation is in line with the finding of Brain (1973:120), who confirms that 'there are distinct terms for ancestors as dead in contrast to living forebears'. As he comments further, Brain observes that 'gifts made to elders are not equivalent to sacrifices made to ancestors'. The data analysed thus far have confirmed that the concept of intermediaries is widespread in African societies, Bapedi society inclusive. For example, Bapedi feel that it is disrespectful to approach God directly but alternatively employ their ancestors as their intermediaries to God. In Bapedi society, it is also customary for the children to communicate with their fathers through their mothers or either older brothers or older sisters. The same applies to approaching the chief. There are always nominated people in the royal family chosen by the chief to serve as the mediators between the community and the chief. Approaching the chief directly is an irregularity - misbehaviour as well as an offence - that is punishable by customary law as per discretion by the chief.

Closer investigation has shown that malopo ritual plays a pivotal role in Bapedi society and serves as a link between the ancestors and their offspring. This communication with the ancestors is often facilitated by traditional healers, who participate in malopo rituals. It has become evident through interviews and observations that the therapeutic function of

10.For an overview of the links between music, culture and society, Wells (1996) argues that 'musical styles are the product of, and a comment upon, socia identities set within specific socio-cultural parameters, necessarily existing in time'. malopo rituals is not confined to the spiritual and physical healing of both the traditional healers and their trainees during the dance only, but also strengthens the healing power of the traditional healers, through communication with their ancestors. So far in this study, we have found that malopo music in Bapedi society supports the feeling of belonging and togetherness of the community.

\section{Conclusion}

Based on the research findings of this study, it is evident that malopo songs are performed to establish and maintain contact with ancestors. The study has demonstrated that, in Bapedi society, ancestors play an important role in the daily lives of their offspring. They oversee the moral behaviour of the individual, the family, the clan and the entire society. The continuing relationship of families with their ancestors has moral, biological and social implications and improves wellbeing and health. Furthermore, it was found that when Bapedi ancestors need to be consulted and appeased, the most effective ways of reaching them are through music and dance - malopo ritual - as well as divination bones. The present investigation has revealed that for health problems associated with ancestral spirits, ancestor veneration such as the malopo ritual is a necessity to appease the personal ancestor of the possessed trainee or traditional healer in particular and the ancestors of the clan and/or tribe in general. The impression created during interviews and observations was that defying ancestors' instructions might cause one to suffer from ill health, sleepless nights and even to have frightening experiences. The study contributes to the notion that the malopo ritual is the most important medium of communication in the social and religious contexts of ancestor veneration in Bapedi tradition. The findings of this study suggest that research in this context should be viewed as an ongoing way of offering new interpretations of the social, religious and cultural significance of ancestor veneration in the Sepedi context. My hope is that this study will be of interest to scholars in the fields of indigenous knowledge systems, African musical arts and African religion and spirituality.

\section{Acknowledgements}

The author is very grateful to the traditional healers who participated in this study and for sharing their knowledge on ancestor veneration as a product of Bapedi people who are bound together with common traditional religion, music and cultural values, as well as the relationship between culture, music and identity in veneration. I also thank the anonymous reviewers for their constructive comments. I have found these comments helpful for the advancement of my research career.

\section{Competing interests}

The author declares that he has no financial or personal relationships which may have inappropriately influenced him in writing this article. 


\section{References}

Berliner, P., 1981, The Soul of Mbira, University of California Press, Berkeley, CA.

Boddy, J., 1994, 'Spirit possession revisited: Beyond instrumentality', Annual Reviews of Anthropology 23, 407-434. https://doi.org/10.1146/annurev.an.23.100194.002203

Brain, J., 1973, 'Ancestors and elders in Africa - Further thoughts', Africa 43(2), 122-133. https://doi.org/10.2307/1159324

Comaroff, J., 1985, Body of power, spirit of resistance: The culture and history of a South African people, University of Chicago Press, Chicago, IL.

Davhula, M.J., 2008, 'Malombo musical arts in Vhavenda indigenous healing practices', Unpublished doctoral thesis, University of Pretoria, Pretoria.

Ephirim, D.A., 1997, African spirituality on becoming ancestors, African World Press, Trenton, NJ.

Etuk, U.A., 2002, Religion and cultural identity, Hope Publication, Ibadan.

Firth, R, Beattie, J \& Middleton, J., 1969, Spirit mediumship and society in Africa, Africana Publishing Corporation, New York.

Garfias, R., 2004, Music: The cultural contexts, National Museum of Ethnology, Osaka.

Gouk, P., 2000, Musical healing in cultural contexts, Ashgate Publishing Limited, Aldershot, England.

Gray, J., 1991, African music: A bibliographical guide to the traditional, popular, art and liturgical musics of sub-Saharan Africa, African Special Bibliography Series, No.14, Greenwood Press, New York.

Hammond, N., 2004, 'Singing South Africanness: The construction of identity among South African youth choirs', in A. Herbst \& H. Potgieter (eds.), Journal of the Musical Arts in Africa, 1, 103-115, University of Cape Town, Cape Town.

Hindley, M., 1982, The Larousse encyclopedia of Music, Excalibur Books, New York.

Huskisson, Y., 1958, 'The social and ceremonial music of the Pedi', PhD thesis, University of Witwatersrand, Johannesburg.

Idang, G.E., 2015, African culture and values, Pronimon 16(2), 1-13.

Imasogie, O., 1985, African traditional religion, Ibadan University Press, Ibadan.

Kongo, P.Z., 1997, Music and healing in Kongo Area. Western central Africa, Conference Paper, Sept. 3-5, 1997, International Centre for African Music and Dance, University of Ghana, Accra.
Lebaka, M.E.K., 2017, Transmission processes of Indigenous Pedi music, University Library of Jyväskylä, Jyväskylä, Finland.

Mashabela, J.K., 2017, 'Healing in a cultural context: The role of healing as a defining character in the growth and popular faith of the Zion Christian Church', Studia Historiae Ecclesiasticae 43(3), 1-14.

Mbiti, J.S., 1970, African religions and philosophy, Heinemann, London.

Merriam, A., 1982, African music in perspective, Garland, New York.

Mönnig, H.O., 1967, The Pedi, J. L. van Schaik, Pretoria.

Mugovhani, N.G., 2015, 'Emerging trends from indigenous music and dance practices: A glimpse into contemporary Malende and Tshigombela', Southern African Journal for Folklore Studies 25(Suppl 1), pp. s81-s96.

Nurnberger, K., 2007, The living dead and the living God. Christ and the ancestors in a changing Africa, Cluster Publications, Pietermaritzburg.

Nzewi, M.E., 1991, 'Backcloth to music and healing in traditional African society', Voices 2(1), 1-4.

Nzewi, M.E., 2003, 'Acquiring knowledge on musical arts in traditional society', in A. Herbst, M. Nzewi \& K. Agawu (eds.), Musical arts in Africa: Theory, practice and education, pp. 13-37, University of South Africa, Pretoria.

Olivier, L., 1985, A comparative psychological study between the dingaka tša malopo (malopo doctors), mediums and ordinary members of the Kgaga of Maake, Human Sciences Research Council, Pretoria.

Omibiyi-Obidike, M.A., 1998, 'African musical resources and African identity in the new African art music', in M.A. Omibiyi-Obidike (ed.), African art music in Nigeria, pp. 150-160, Stirling-Horden Publishers, Ibadan.

Ray, B.C., 1976, African religions: Symbol, ritual and community, Prentice Hall, Englewood cliffs, NJ.

Van der Hooft, G.A., 1979, Malopodans - Een transcultureel-psychiatrische studie, Rodopi, Amsterdam.

Wells, R., 1996, 'Sesotho music: A contemporary perspective', African Music: Journal of the International Library of African Music 7(3), 67-76. https://doi.org/10.21504/ amj.v7i3.1965

Willoughby, W.C., 1928, The soul of the Bantu. A sympathetic study of the magicoreligious practices and beliefs of the Bantu Tribes of Africa, Student Christian Movement, London. 